\title{
Pravoslaví jako součást veřejné prezentace romanovské monarchie za Mikuláše II.
}

\section{The Orthodoxy as a Part of the Public Presentation of the Romanov Monarchy under Nicholas II}

\author{
Zbyněk Vydra / zbynek.vydra@upc.cz \\ Ústav historických věd, Fakulta filozofická, Univerzita Pardubice, Pardubice
}

\begin{abstract}
The article is focused on the role of the orthodoxy in the public presentation of the Russian monarchy under the Nicholas II (1894-1917). Author analyzes two public events connected closely with the orthodoxy, in which Nicholas II played a key role. The canonization of Serafim of Sarov in 1903 and the celebration of the Romanov Tercentenary in 1913 were conceived as a great public festivities which had to bring the emperor and the people together. Both events presented the tsar as very pious man who cared deeply for the people. However, the longterm effect of such presentation was dubious, because the ordinary people, mostly peasants, remained rather indifferent to the state ideology "orthodoxy, autocracy, nationality".
\end{abstract}

\section{Key words}

Russia, 19. century, 20. century, Nicholas II, orthodoxy, autocracy 
Monarchie v Evropě v 19. století procházely procesem postupné transformace. Nástup moderních politických ideologií a výzvy v podobě revolucí, Velkou francouzskou revolucí počínaje, s sebou přinášely nový koncept občanské společnosti, rovnosti před zákonem a s těmito fakty se musely monarchie a jejich vládci vyrovnat. Zatímco většina evropských států postupně přijala koncepci „buržoazní monarchie“, v níž panovník hrál spíše symbolickou, přesto však důležitou, roli osobnosti ztělesňující stát, historickou tradici a tmelící národ $/ \mathrm{y},{ }^{1}$ Rusko v zásadě zůstávalo věrné dosavadnímu pojetí monarchie jako instituce božského původu. ${ }^{2}$

Tradiční pojetí monarchie dostalo mocnou ideologickou oporu za vlády Mikuláše I., který pečlivě sledoval dění na západ od Ruska a uvědomoval si nebezpečí revolucí. Hned při svém nástupu na trůn byl konfrontován s povstáním děkabristů, což zásadně ovlivnilo celé jeho panování. Navíc v roce 1830 došlo k červencové revoluci ve Francii, následně revoluci v Belgii a vypuklo protiruské povstání v Polsku. Revoluční myšlenky silně rezonovaly v německých a italských státech a Mikuláš I. nehodlal dopustit jejich šíření v ruském impériu. ${ }^{3}$ Carská politika se však nehodlala spoléhat pouze na represe v podobě posilování cenzury a tajné policie. Štítem proti revolucím se měla stát nová oficiální státní ideologie pravoslaví, samoděržaví, národ, po svém duchovním otci hraběti Sergeji S. Uvarovovi, tehdejším ministru lidové osvěty, často přezdívaná jako tzv. uvarovská triáda. ${ }^{4}$ Tato ideologie představovala jeden z výrazných prvků kontinuity v státní politice od 30. let 19. století až do konečného pádu monarchie únoru/březnu 1917. Žádný z carů po Mikuláši I. se triády nezřekl, ani Alexandr II. v liberální fázi své vlády. Za Alexandra III. a Mikuláše II. dokonce důraz na jednotlivé prvky triády posiloval. Ani po roce 1906, kdy byla zřízena Státní duma a Rusko se de facto stalo konstituční monarchií, nedošlo k zavržení oficiální ideologie, tedy ani principu samoděržaví.

1 Ke koncepci tzv. buržoazní monarchie viz Döllinger, Heinz: Das Leitbild des Burgerkönigtums in der Europäischen Monarchie des 19. Jahrhunderts, in: Hof, Kultur, und Politik im 19. Jahrhundert, Ed. K. F. Werner. Bonn 1985, s. 325-362. Dále srov. Hofgesellschaft in den deutschen Staaten im 19. und beginnenden 20. Jahrhundert, Ed. K. Möckl. Boppard am Rhein 1990; Giloi, Eva: Monarchy, Myth, and Material Culture in Germany, 1750-1950. Cambridge 2013, zejména s. 79-83, 329-344; Wolf, Christiane: Representing Constitutional Monarchy in Late Nineteenth and Early Twentieth-Century Britain, Germany and Austria, in: The Limits of Loyalty. Imperial Symbolism, Popular Allegiances, and State Patriotism in the Late Habsburg Monarchy. Eds. L. Cole - D. L. Unowsky. New York 2007, s. 199-222.

2 Americký historik Richard Wortman ve své zásadní práci o proměnách veřejného obrazu romanovské monarchie poukazuje na fakt, že Mikuláš I. přijal z koncepce buržoazní monarchie zejména důraz na rodinu jako základ státu, symbol oddanosti a vzájemné úcty. Carská rodina měla být v tomto ohledu vzorem a takto se prezentovala na veřejnosti. Tím ovšem podobnost s buržoazní monarchií končila. Vzhledem k přetrvávajícímu důrazu na samoděržavný ráz ruské monarchie nebylo možné, aby car vyklidil pole ve sféře politického rozhodování. Wortman, Richard: Scenarios of Power. Myth and Ceremony in Russian Monarchy. From Peter the Great to the Abdication of Nicholas II. Princeton 2006, k Mikuláši I. zvláště kapitoly č. 7, 8 a 9, s. $120-188$.

3 Srov. Svoboda, Karel Veřejné míněni a revoluce 1830-1831, Studia territorialia 10, č. 1 (2010), s. 55-80; Lincoln, Bruce W.: Nicholas I, Emperor and Autocrat of All the Russias. DeKalb 1989, s. 130-143.

4 Základní monografií zůstává: Riasanovsky, Nicholas:Nicholas I and Official Nationality in Russia, $1825-1855$. Berkeley - Los Angeles 1959. Dále srov. Lincoln, B. W.: Nicholas I, s. 239-252. Literární a kulturní kontext vzniku oficiální státní ideologie: Zorin, Andrej Kormja dvuglavogo orla: literatura i gosudarstvennaja ideologija v Rossii v poslednej treti XVIII - pervoj treti XIX veka. Moskva 2001. 
Tato studie se zaměřuje na období vlády Mikuláše II. (1894-1917), přičemž naše pozornost se soustředí na první pilî́r uvarovské triády - pravoslaví. Pro ilustraci role pravoslaví ve veřejné prezentaci romanovské monarchie jsme zvolili dva důležité okamžiky, které od sebe oddělovala deset bouřlivých let. Kanonizace Serafima Sarovského v létě 1903 byla momentem, kdy se Mikuláš II. prezentoval jako „zbožný car“ a jakoby se vracel k tradici prvních romanovských carů (zejména Alexeje Michajloviče). Romanovské jubileum v roce 1913 oslavovalo tři sta let dynastie v Rusku, se záměrem ukázat stabilitu monarchie a oblíbenost dynastie ve společnosti. Tím měly být zapomenuty politické turbulence posledních let, především revoluce z let 1905-1906. Našimi hlavními prameny pro vylíčení událostí obou let a jejich analýzu jsou zejména dobové tiskoviny, deníky a memoáry osobností z carova okruhu, včetně deníků Mikuláše II.

V systému samoděržavné monarchie osobnost panovníka hrála klíčovou roli. Mikuláše II. podstatným způsobem formovalo rodinné prostředí. Jeho otec Alexandr III. byl silně zbožný, nacionalisticky orientovaný a neochvějně věřil v samoděržaví. Politický program Alexandra III. se zásadně opíral o uvarovskou triádu a přikládal velkou váhu posilování pravoslaví / pravoslavné církve. Důležitou roli přitom hrál vrchní prokurátor Nejsvětějš́ího synodu Konstantin P. Pobědonoscev, klíčová postava carské vlády. ${ }^{5}$ Počet základních farních škol vzrostl za vlády Alexandra III. z přibližně 4500 na 32000 a počet žáků/žákyň v nich se zdesateronásobil na více než jeden milion. V letech 1881-1890 bylo založeno 160 nových klášterů a položeny základy více než 5000 nových kostelů jejich výstavba byla $\mathrm{v}$ mnoha případech součástí kulturní rusifikace periferních částí ruského impéria (Chrám Alexandra Něvského v Tallinnu, 1894-1900; Chrám Alexandra Něvského ve Varšavě, 1894-1912), respektive prosazování tzv. autentického ruského ducha v kosmopolitním prostředí (Chrám Kristova vzkřrišení v Petrohradu). Za povšimnutí dále stojí skutečnost, že za vlády Alexandra III. a ještě více za Mikuláše II. pravoslavní duchovní dostávali od státu vysoká vyznamenání. Za třináct let vlády Alexandra III. třicet pět představitelů duchovního stavu bylo dekorováno Ǩádem Sv. Alexandra

5 Pobědonoscev nejenže dohlížel nad pravoslavnou církví, ale přímo formuloval státní ideologickou politiku. Byl hlavním autorem manifestu Alexandra III., v kterém se car při nástupu na trůn v roce 1881 jasně vymezil proti liberálním reformám Alexandra II. a podtrhl kontinuitu uvarovské ideologie, zejména zdůrazněním samoděržaví. V sovětské historiografii Pobědonoscev sloužil jako symbol „reakční politiky“ carského režimu. Viz Zajončkovskij, Petr A. Krizis samoděržavija na rubeže 1870-188-ch gg. Moskva 1964; Týž: Rossijskoje samoděržavije v konce XIX stoletija. Moskva 1970. V posledních cirka deseti letech odborný zájem o jeho osobu roste, i v souvislosti s obecně širším a důkladnějším studiem ruského konzervativismu. Z literatury poslední doby srov. především Polunov, Alexandr J.: K. P. Pobedonoscev v obščestvenno- političeskoj i duchovnoj žizni Rossii. Moskva 2010. Z české odborné produkce srov. Vlček, Radomír: Ke kořenům ruského politického konzervatismu (Konstantin Pobědonoscev). Sborník prací Pedagogické fakulty Masarykovy univerzity. Řada Společenských věd, roč. 26, č. 2 (2012), s. 92-101. V anglosaské historiografii zůstává nejpodrobnějším životopisem již poměrně stará monografie: Byrnes, Robert F.: Pobedonostsev. His Life and Thouht. Bloomington 1968. K ruskému konzervatismu dále srov. Russkij konservatizm XIX stoletija. Ideologija i praktika. Ed. V. Ja. Grosul. Moskva 2000; Rossijskije konservatory. Moskva 1997; Russkij konservatizm serediny XVIII-načala XX veka: enciklopedija, red. Valentin V. Šelochajev, Moskva 2010. Inspirativní diskuzi ruských historiků přinesla rubrika Kruglyj stol na téma Russkij konservatizm: problemy, podchody, mnenija, in: Otečestvennaja istorija 3 (2001), s 103-133. 
Něvského, za třiadvacetileté vlády Mikuláše II. dokonce sedmdesát čtyři. Přitom Alexandr II. za dvacet šest let panování vyznamenal pouze dvacet osm duchovních. ${ }^{6}$

Oproti Mikuláši I. či Alexandru II., jejichž mocenský scénář navazoval na obraz Petra I. coby „evropského panovníka“ se Alexandr III. podstatně více stylizoval do role „pravého Rusa“ a „cara-bohatýra“, což bylo dáno nejen jeho charakterovými vlastnostmi, ale i fyzickými dispozicemi. Mikuláš II. nezdědil po otci statnou postavu a udivující fyzickou sílu, osvojil si však hluboké náboženské cítění. ${ }^{7} \mathrm{Na}$ rozdíl od řady monarchů-vrstevníků, kteří již prošli veřejným vzdělávacím systémem ${ }^{8}$, Mikuláš byl vychováván v relativní izolaci od vnějších vlivů, přičemž k jeho domácím učitelům patřil i výše zmíněný Konstantin Pobědonoscev. I díky jeho působení Mikuláš II. po nástupu na trůn v roce 1894 bez nejmenších pochybností převzal dosavadní konzervativní politický kurs a odmítl jakoukoli liberalizaci.

Mikuláši II. imponovalo vše spojené s tradicemi moskevského carství. Nadšení v něm vyvolala již návštěva Moskvy v červenci 1881, kdy mu bylo třináct let. ${ }^{9}$ Do Moskvy se v následujících letech vždy rád vracel. Symbolický význam měly velikonoční cesty, vytvářející paralelu mezi ním a zbožnými moskevskými cary. K takovým cestám došlo roku 1900 a $1903 .{ }^{10}$ Naproti tomu dvorské ceremonie v Petrohradě nebyly carovi zvlášt' příjemné, o čemž svědčila už jeho reakce na oslavu plnoletosti 6 . května $1884 .{ }^{11}$ Během své vlády Mikuláš II. jednoznačně dával přednost životu v rodinném kruhu a cestám mimo Petrohrad, na nichž se mohl setkávat s lidem, před opulentními dvorskými plesy a slavnostmi. Do jisté míry přitom byl ovlivněn slavjanofilským pohledem na ruské dějiny, roli cara a samoděržaví. Nedůvěřoval institucím a byrokracii a spoléhal se na nevyřčené a neviditelné duchovní pouto s lidem, o kterém věřil, že přetrvalo z dávných časů „čistého samoděržaví“. I proto kladl zvláštní důraz na vazbu cara a rolnictva.

Z carova niterného přesvědčení vycházel i jeho kulturní a mocenský scénářr, který se snažil realizovat. Situaci mu ztěžovala skutečnost, že v Rusku na přelomu 19. a 20. století probíhal střet několika protikladných sil a proti jeho mocenskému scénáři stála řada dalších. ${ }^{12}$ Mikuláš II., nehodlající měnit zaběhnuté pořádky a toužící po čisté autokra-

6 Rád Sv. Alexandra Něvského byl udělován od roku 1725 za zásluhy o ruský stát. Srov. Kavalery Imperatorskogo ordena Svjatogo Alexandra Nevskogo. 3 vols., Moskva 2009. K státní podoře pravoslavné církve dále srov. Tolmačev, Jevgenij P.: Aleksandr III i jego vremja, Moskva 2007, s. 291. Wortman, R.: Scenarios, s. 285, 288.

7 Wortman, R.: Scenarios, s. 317-318.

8 Anglický král Jiří V. studoval Naval College, německý císař Vilém II. gymnázium, dokonce japonský císař Hirohito chodil do veřejné školy (byt' elitního ústavu pro šlechtice). Lieven, Dominic: Nicholas II. Emperor of All the Russias. London 1993, s. 41.

9 Mikuláš byl uchvácen Kremlem, Chrámem Zesnutí Panny Marie, Chrámem Krista Spasitele, Trojicko-sergijevským klášterem v Sergijev Posadu. Wortman, R.: Scenarios, s. 321.

10 Během druhé návštěvy se car setkal s dělníky sdruženými v odborech organizovaných tajnou policií. Dnevniki Nikolaja II. 1896-1904. Moskva 2011, s. 526-527, 721-722. K „policejním odborům“ srov. Schneiderman, Jeremiah: Sergei Zubatov and the Revolutionary Marxism: The Struggle for the Working Class in Tsarist Russia. Ithaca - London 1976.

11 Zápis v deníku byl velice stručný, carevič si pouze poznamenal, že si oblékl uniformu kozáckého atamana a obdržel pruská, řecká a dánská vyznamenání. Slavnost pro něho znamenala psychickou zátěž, nepř́ijemné vybočení z příjemností každodenního života. Srov. Wortman, R.: Scenarios, s. 321-322.

12 Solidní přehled poměrů v Rusku na přelomu století viz: Pervaja revoljucija v Rossii. Vzgljad čerez stoletije. 
cii, postavené na osobní autoritě vycházející od Boha a ruského lidu, se musel vyrovnat s politicky se probouzející společností, s koncepcí liberální parlamentní monarchie, socialistické republiky nebo anarchistickými představami rolníků toužících po přerozdělení statkářské půdy, k čemuž fakticky stát vůbec nepotřebovali.

Na konci 19. století především začalo zesilovat sociální pnutí vyvolané industrializací posledních dvou dekád. K dělnickým stávkám v Petrohradě (1896-1897) se přidaly rolnické nepoje v řadě gubernií a také studentské demonstrace a stávky. Akce studentů byly motivovány především politicky a souvisely s oživením činnosti ilegálních politických stran (sociální demokracie; strana socialistických revolucionářů, tzv. eserů). Politický protistátní teror představoval obzvlášt’nebezpečný jev. 2. března 1901 byl zavražděn ministr lidové osvěty Nikolaj P. Bogolepov. Dva dny po atentátu policie a vojsko brutálně rozehnaly masovou demonstraci na Kazaňském náměstí v Petrohradě; pozatýkáno bylo na 1500 lidí. 2. dubna 1902 eseři zavraždili ministra vnitra Dmitrije S. Sipjagina. ${ }^{13}$

Mikuláš II. tyto události registroval a vnímal je jako hrozbu. Čelit se jim snažil návratem ke kořenům, tedy k idealizovanému „čistému samoděržavi“. Dvorská společnost a zprostředkovaně celá země mohly spatřit realizaci této ideje při velkolepém plesu v Zimním paláci 13. února 1903. Všichni účastníci bálu, a bylo jich přes tři sta, se dostavili v kostýmech z doby vlády cara Alexeje Michajloviče (panoval 1645-1676). Kostýmní ples zůstal největším událostí tohoto druhu, jaká se v Rusku až do revoluce 1917 odehrála. ${ }^{14}$ Dostalo se mu široké publicity. Nejenže bylo vydáno luxusní třídílné album fotografií, zachycující všechny účastníky, ale o plesu psal i denní tisk a petrohradský deník Novoje vremja $\mathrm{v}$ obrazové př́loze postupně otiskl většinu fotografických portrétů z bálu. Zatímco pro mnoho dvořanů se nepochybně jednalo jen o další z řady maškarních plesů, tehdy tolik populárních, pro cara měla událost podstatně hlubší význam. V následujících letech se opakovaně objevovaly portréty Mikuláše II. a Alexandry Fjodorovny $\mathrm{v}$ „kostýmech“ - car byl oblečen do oděvu Alexeje Michajloviče a carevna do šatů Marie Iljiničny Miloslavské, jeho první choti.

Víceméně ve stejné době Mikuláš II. zvýšil frekvenci svých cest po venkově. V srpnu 1902 navštívil kurskou gubernii a setkal se zde s rolníky, konkrétně vybranými volostními staršiny reprezentujícími rolnickou samosprávu. Částečně se tím vracel k scénáři svého děda Alexandra II., který rovněž cestoval po Rusku a účastnil se (zaranžovaných) setkání s rolníky. Mikulášova úprava ovšem sledovala především vyjádření carova zvláštního osobního a duchovního pouta s rolníky, nikoli manifestaci lásky rolníkủ k jejich vládci; podobná setkání totiž nepočítala se spontánními reakcemi veřejnosti. ${ }^{15}$

Častěǰ̌í cesty do gubernií a setkávání s delegacemi rolníkủ byly součástí carského mocenského scénáře, v kterém Mikuláš II. hrál roli zbožného, lidového cara. Nepochybně

Moskva 2005 (zvl. kapitola 1., Istoki rossijskoj revoljucionnoj dramy, s. 21-79). Dále srov. Rossija v načale XX veka. Issledovanije. Moskva 2002.

13 K otázce politického terorismu v Rusku na počátku 20. století srov. Geifman, Anna: Thou Shalt Kill. Revolutionary Terrorism in Russia, 1894-1917. Princeton 1995.

14 Kostjumirovannyj bal v Zimnem dvorce. 2 vols. St. Peterburg 2003; Vojejkov, Vladimir N.: S carjem i bez carja. Helsinki 1936 (reprint Moskva 1995), s. 56-61. Dále srov. Wortman, R.: Scenarios, s. 355.

Wortman, R.: Scenarios, s. 355. 
souvisely s politickou a sociální situací v zemi (byt’z carova deníku nelze vydedukovat, že by se jednalo o jím promyšlenou strategii získávání veřejné podpory). Vyloučit nelze ani snahu překonat „prokletí Chodynky“, tedy dát zapomenout na tragédii, která se odehrála při oslavách korunovace Mikuláše II. v Moskvě v druhé polovině května 1896. Tehdy při lidové veselici na Chodynském poli bylo v panice ušlapáno přes tisíc lidí. Car nepřerušil oficiální oslavy, čímž si vysloužil značnou kritiku doma i v zahraničí a tragédie vrhla stín na celou jeho vládu. Jelikož Mikulášovi rozhodně nebyl cizí fatalismus, i on v průběhu let uvěřil v nepřízeň osudu a s „hříchem Chodynky“ si spojoval počátek svých starostí. ${ }^{16}$

Carské cesty po impériu v sobě vždy nesly silný duchovní náboj. Návštěvy klášterů, klanění se svatým ostatkům a ikonám byly přirozeným vyjádřením úcty k historickým tradicím a zdůrazněním významu pravoslavné víry pro současný ruský život. Obsahovaly ovšem i mnohem intimnější rozměr. Rozhodně v dané chvíli souvisely s touhou carských manželů po narození syna a s intenzivní četbou mystických textů a životopisů svatých carevnou Alexandrou Fjodorovnou. Carevna byla velmi ovlivněna dobovou mystickou literaturou (západoevropskou i ruskou), silně si idealizovala ruskou lidovou zbožnost a shlédla se v postavách starců, které pokládala za symbol ruské lidové zbožnosti, křestanské pokory a askeze. Carevniny mystické sklony otevíraly dveře ke dvoru nejrůznějším dobrodruhům a šarlatánům a jedním z nich byl francouzský mystik Philipp Nizier-Vachot z Lyonu. ${ }^{17}$ „Monsier Philipp“ v roce 1902 doporučil carevně svatořečení Serafima Sarovského, což se zdálo obzvlášt’vhodné nejen proto, že kult Serafima představoval protipól mariánskému kultu v katolické církvi a Sarov se měl stát ruskou obdobou Lourdes, ale na 2. ledna 1903 připadalo výročí 70 let od Serafimova úmrtí. ${ }^{18}$

Podnět k svatořečení Serafima Sarovského, vzešlý od „Monsieur Philippa“, rozhodně nebyl ojedinělý. Spíše ve vhodnou dobu doplnil obdobně znějící hlasy a dodal jim větší váhy. Serafim byl dlouhodobě oblíbenou postavou. Narodil se pravděpodobně roku 1759 v Kursku, 13. srpna 1786 vstoupil do sarovského kláštera v tambovské gubernii (dnes nižegoroská oblast) a přijal mnišské jméno Serafim. Získal si širokou oblibu mezi lidem jako léčitel, zpovědník a prorok. Proslul rovněž sebeodříkáním, řadu let žil téměř jako poustevník v lesní chýši a do kláštera docházel pouze na bohoslužby. Serafim propagoval kult panenské čistoty a ještě za jeho života se sarovský klášter stal místem náboženských poutí. ${ }^{19}$ Serafimův kult byl silný také u carského dvora, uctívaly jej carevny Ale-

16 Iswolsky, Alexander: The Memoirs of Alexander Iswolsky. Formerly Russian Minister of Foreign Affairs and Ambassador to France. London 1920, s. 257-263; Tichomirov, Lev A.: 25 let nazad. Krasnyj Archiv II (XXXIX), 1930, s. 53, 72. V sekundární literatuře stručně viz Wortman, R.: Scenarios, s. 343-346. Pro širší politické souvislosti srov. Vlček, Radomír: Korunovace cara Mikuláše II. a tragédie na chodynském poli jako obraz ruského konzervatismu 19. Století. Slovanský přehled 83, č. 3, (1997,) s. 257-274.

17 Anthelme Nizier Philippe (Philippe-Vachot) se narodil roku 1849 v Savojsku, pocházel z rolnické rodiny. Již ve věku 13 let proslul jako léčitel. Později získal značnou popularitu jako „tvůrce zázraků“ mezi pařížskými okultisty. Snad v roce 1900 se setkal ve Francii s velkoknížetem Vladimirem Alexandrovičem, čímž se mu otevřela cesta do Ruska. Zemřel roku 1905.

18 Smert' pravednych i končina velikogo starca Serafima Sarovskogo (2 janvarja 1833-1903 gg.). Pribavlenija k cerkovnym vedomostjam, č. 4, 25. 1. 1903, s. 112-115; Končina prepodobnogo Serafima, Sarovskogo čudotvorca. Pribavlenija k cerkovnym vedomostjam, č. 5, 1. 2. 1903, s. 148-156.

19 Základní přehled: Wortman, R.: Scenarios of Power, s. 356-359. Podrobně např. Nichols, Robert L.: The Friends of God: Nicholas II and Alexandra at the Canonization of Serafim of Sarov, July 1903. In: Religious and 
xandra Fjodorovna (chot’Mikuláše I.) i Marie Alexandrovna (manželka Alexandra II.).

Hnutí za Serafimovo svatořečení začalo sílit v 90 . letech 19. století, nemělo však podporu Nejsvětějš́ího synodu, ani nejvy̌šśí církevní hierarchie. ${ }^{20}$ Iniciativa vycházela spíše od nižšího kléru, což samo o sobě muselo na vrchního prokurátora Synodu Pobědonosceva, tradičně odmítajícího spontánní aktivity „zdola“, působit podezřele. Zároveň to svědčí o vnitřním pnutí uvnitř pravoslavné církve, která na konci 19. století rozhodně nebyla jednotná a zejména řadoví farní kněží se více a více dovolávali reformy. Výjimkou nebyly ani hlasy dožadující se obnovení patriarchátu a nezávislosti církve na státu. ${ }^{21}$ Každopádně množící se žádosti o svatořečení Serafima nebylo možné stále ignorovat. V letech 1892-1894 zvláštní komise posuzovala zázraky vykonané Serafimem; šetření probíhalo v dvaceti osmi eparchiích evropského Ruska a Sibiře. Komise prověřila devadesát čtyři př́ípadů zázraků v důsledku Serafimových modliteb a většinu z nich uznala za hodnověrné ${ }^{22}$ Bezprostřední výsledek z toho ovšem nevyplynul a je zřejmé, že zásadní zlom přinesla až přímá intervence z carského dvora. Carevna Alexandra sdělila Pobědonoscevovi, že požaduje urychlené Serafimovo svatořečení. Pobědonoscev namítal, že se jedná o zdlouhavý a komplikovaný proces s řadou nezbytných úkonů; carevna jej údajně odbyla slovy „Car může cokoli“. Následně dostal Probědonoscev př́kaz od samotného cara, v němž žádal realizaci kanonizace během následujícího roku. Bytje pravděpodobné, že tato historka není zdaleka přesná, nebot' car si dobře uvědomoval složité procedury spojené se svatořečením, svědčí minimálně o eminentním zájmu Mikuláše II. a Alexandry Fjodorovny na celém případu. ${ }^{23}$

Synod vyslovil souhlas se svatořečením Serafima 29. ledna 1903 a pověřil Antonije, petrohradského a ladožského metropolitu, aby spolu s tambovským biskupem Dmitrijem a nižegorodským biskupem Nazarijem provedli 19. července slavností odkrytí Serafimových ostatků. ${ }^{24} \mathrm{~V}$ následujících měsících se v oficiálním církevním tisku objevovaly průběžné hagiografické texty o Serafimovi, jeho životě a zázracích, jež vykonal. ${ }^{25}$

Secular Forces in Late Tsarist Russia. Essays in Honor of Donald W. Treadgold. Ed. Ch. E. Timberlake. Seattle - London 1992, s. 206-229.

20 Propagátorem kultu Serafima a jedním z iniciátorů kanonizace byl mnich Serafim (vl. Jménem Leonid Čičagov, 1856-1937). Sloužil v armádě, kde dosáhl hodnosti kapitána carské gardy. V roce 1890 odešel do výslužby a věnoval se duchovní kariére. Po smrti manželky (1895) vstoupil do kláštera. Měl dobré kontakty u carského dvora díky vojenské službě a tomu, že jeho žena byla dcerou komoř́ho carského dvora Dochturova. Při jednom setkání s Mikulášem II. mu předal své spisy o Serafimu Sarovském. Intenzivní snahu Serafima-Čičagova o kanonizaci zmiňuje též Mosolov, Alexandr A.: Pri dvore imperátora. Riga s. d., s. 100. Biografické údaje o Serafimu-Čičagovovi viz Černaja sotnja. Istoričeskaja enciklopedija. Moskva 2008, s. 477-480; Dneuniki Nikolaja II, vol. 1, s. 775.

21 O pravoslavné církvi v Rusku v 19. století, jejím vztahu k státu a společnosti viz Freeze, Gregory L.: Russian Orthodoxy: Church, people and politics in Imperial Russia. In: The Cambridge History of Russia. vol. 2. Imperial Russia, 1689-1917. Ed. D. Lieven. Cambridge 2006, s. 284-305.

22 Cerkovnyja vedomosti, č. 5 (1. 2. 1903), s. 31.

23 Nichols, R.: The Friends of God, s. 215.

24 Cerkovnyja vedomosti, č. 5 (1. 2. 1903), s. 33.

25 Srov. Predstojaščeje pravoslavnoj Rossii. Svetloje i velikoje toržestvo. In: Pribavlenija k cerkovnym vedomostjam, izdavajemym pri Svjatejšem pravitelstvujuščem synode, č. 16 (19. 4. 1903), s. 593-602; Zavety Sarouskogo podvižnika i jego duchovnyj obraz, Tamtéž, č. 24 (14. 6. 1903), s. 901-907. 
Kanonizace Serafima byla carovi prostředkem ke sblížení s masami. Generál Alexandr A. Mosolov (vedoucí kanceláře ministerstva carského dvora v letech 1900-1916), byl obdobně jako Mikuláše II. přesvědčen o nutnosti překonat bariéru, kterou mezi panovníkem a lidem vytvářela byrokracie. Přímé setkávání cara s prostým lidem, především rolníky a vojáky, k tomu bylo vhodnou cestou. Rovněž ministr vnitra Vjačeslav K. Pleve zamýšlel pojmout kanonizaci Serafima jako velkou lidovou oslavu a tím ukázat ,jednotu cara a lidu. “ ${ }^{26}$ Slavnosti se tedy nepochybně staly jednou z hlavních událostí roku, kdy se car s carevnou vymanili z izolace dvora, petrohradského života a „představili se lidu“, čímž i vyjádřili svou sounáležitost s ním.

$\mathrm{Z}$ osob u carského dvora se v kanonizaci a slavnostech s ní spojených výrazně angažoval kníže Michail S. Putjatin, jeden z oblíbenců Mikuláše II. Spolu s archimandritou Serafimem a knížetem Alexejem A. Širinským-Šichmatovem, prokurátorem moskevské synodální kanceláře, byl Putjatin vyslán do Sarova, aby dohlížel na organizaci kanonizačních slavností. ${ }^{27}$ Př́pravy přímo na místě začaly 3 . července. Serafimovy ostatky byly vyzvednuty z hrobu a přemístěny do nové rakve, zdobené ornamenty v staroruském stylu, vyrobené z cypřišového dřeva na návrh knížete Putjatina. Slavnosti oficiálně začaly v úterý 15. července a trvaly do pondělí 21. července. Detailní program byl oficiálně oznámen tiskem s měsíčním předstihem. ${ }^{28}$

Car s carevnou, několika členy širší romanovské rodiny ${ }^{29}$ a svitou, která je obvykle provázela při pravidelných cestách na Krym, odjeli 15. července z Petěrhofu a 17. července ráno dorazili na speciálně postavené provisorní nádraží u vesnice Vyjezdnaja Sloboda, ještě před pravidelnou zastávkou v Arzamasu v nižegorodské gubernii. Odtud pokračovali kočáry s čtyřspřežím do Sarova. Při průjezdu přes hranici nižegorodské a tambovské gubernie projeli slavobránou, kde je uvítali tambovský gubernátor von-der-Launitz a další významní činitelé guberniální státní správy, zemské samosprávy a rolnické delegace. Vedle místní šlechty nemohli přirozeně chybět rolníci, přičemž ženy se oblékli do zdobených krojü ${ }^{30}$. Čím více se carská kolona přibližovala k Sarovu, tím potkávala více poutníků. Podle dobových odhadů jich přišlo na 150 tisíc, hovořilo se ovšem i půl milionu lidí. ${ }^{31}$ Většinou se jednalo o rolníky. Slovy Mosolova, , ,car byl presvědčen, že lid jej upř́mně miluje a v̌sechny rebelie jsou pouze nánosem zvenčí, výsledkem propagan-

26 Solovjev, Jurij B.: Samoderžavije i dvorjanstvo v 1902-1907gg. Leningrad 1981, s. 75.

27 Cerkovnyja vedomosti, č. 5, 1. 2. 1903, s. 34; Mosolov, A. A.: Pri dvore imperatora, s. 101; Dnevniki Nikolaja II. vol. 1, s. 699, 705 .

28 Ceremonial toržestvennago otkrytija sujatych moščej prepodobnago o. Serafima, Sarovskago čudotvorca. Cerkovnyja vedomosti, č. 24 (14. 6. 1903), s. 250. Průběh sarovských slavností lze dobře zrekonstruovat na základě článků v denním tisku. Reportáže o průběhu kanonizace a slavností: Sarovskija toržestva, Niva, č. 31 (1903), s. 622-628; Niva, č. 32 (1903), s. 642-644. Reportáž o historii Sarovského kláštera a Serafimově životě: $S a$ rouskaja pustyň i o. Serafim - sarouskij podvižnik, Niva, č. 28 (1903), s. 556-562.

29 Cesty se účastnili carevna matka Marie Fjodorovna, velkoknížata Sergej Alexandrovič, Nikolaj Nikolajevič a Petr Nikolajevič s manželkami; dále velkokněžny Anastázie Nikolajevna a carova mladší sestra velkokněžna Olga Alexandrovna, obě s manžely.

30 Sarouskija toržestva, Niva, č. 31 (1903), s. 626.

31 Tamtéž, s. 622; Mosolov, A. A.: Pri dvore imperatora, s. 102; Nichols, R.. The Friends of God, s. 209. 
dy mocichtivé inteligence. (...) „Ani mně, ani nikomu car nevyprávěl své dojmy zcela otevřeně. “32 Mosolov svůj názor odvozoval z dlouholeté zkušenosti a znalosti dvorského prostředí, v němž se předávala carova slova a panovníkovy názory tudíž byly široce známé.

Do Sarova průvod dorazil v podvečer. 17. červenec přinesl první vrchol oslav, nebot' vedle carova př́ijezdu dorazilo do Sarovského kláštera obří lidové procesí, nesoucí ikonu Dojetí (Umilenija) Bohorodičky z Divejevského kláštera; stejnou ikonu, před kterou Serafim zemřel. Ráno 18. července car s carevnou navštívili ranní mši v Chrámu Zesnutí Panny Marie (Uspenskij sobor), k značnému překvapení prostých věřících, nebot'se dostavili sami bez svity. Většinu dne carský pár věnoval prohlídce kláštera a míst spojených s životem Serafima. Hlavní slavnost začala večer v šest hodin. V čele car s velkoknížaty nesl Serafimovu rakev, za nimi následoval zástup s carevnou a petrohradským metropolitou Antonijem v první řadě. Z dalších významných církevních hodnostářu byli přítomni kazaňský arcibiskup Dimitrij, nově jmenovaný tambovský biskup Innokentij a nižegorodský a armazský biskup Nazarij. Car a velkoknížata třikrát obešli s rakví Chrám Zesnutí Panny Marie, na každé světové straně chrámu se pomodlili, a přenesli ostatky dovnitř chrámu. Tambovský biskup Innokentij pronesl řeč a poté následovalo klanění ostatkům a jejich pocelování. Serafimovy ostatky byly slavnostně uloženy do nového hrobu ráno 19. července. Odpoledne se konala tř́ihodinová slavnostní hostina, po jejímž skončení car krátce sešel se zástupci tambovské šlechty. Téhož dne byla kanonizace slavnostně oznámena při bohoslužbě ve všech ruských chrámech. 20. července slavnosti oficiálně skončily. Carská rodina navštívila před odjezdem ženský Divejevský klášter v nižegorodské gubernii. Klášter byl založen z iniciativy Serafima Sarovského a dnes je v něm uchován jediný autentický portrét Serafima. Po cestě byl jako obvykle zdraven rolníky a zástupci šlechty. ${ }^{33}$

Nedílnou součástí sarovských slavností bylo koupání poutníků v místním potoce, jehož léčivé účinky byly součástí serafimovské legendy. Petrohradský metropolita Antonij ve své oficiální zprávě Nejsvětějšímu synodu, obratem otištěné v oficiálním tisku, uvedl pět konkrétních zázraků př́imo z průběhu oslav poté, co se poutníci vykoupali v sarovském potoku. Např́íklad se jednalo o dvanáctiletého rolnického chlapce Vasilije Jovleva z jenisejské gubernie, od narození němého, jemuž se po koupeli navrátila řeč. Osmnáctiletá rolnická dívka Agripina Tabajeva ze simbirské gubernie, slepá od narození, se třikrát vykoupala v potoce a po druhé koupeli uzřela sluneční svit a začala rozlišovat předměty. Padesátiletý měštan Vasilij Bogomolov ze Spassku v rjazaňské gubernii, již sedm let nepohyblivý, s paralýzou řeči i sluchu, byl přivezen k potoku a vykoupán, načež začal slyšet, mluvit a chodit. Mimo léčivý sarovský potok se zázraky odehrály i v blízkosti Serafimových ostatků. ${ }^{34} \mathrm{~A}$ když se carevně Alexandře Fjodorovně, která se rovněž v potoce vykoupala, narodil 30. července 1904 syn Alexej, význam Serafimova kultu pro

32 Mosolov, A. A.: Pri dvore imperatora, s. 102.

33 Sarovskija toržestva, Niva, č. 31 (1903), s. 627. Srov. Dnevniki Nikolaja II., vol. 1, s. 740-741.

34 Donesenije Svatejšemu Pravitelstvujǔ̌čemu Synodu Pervenstvujuščago Člena onago Antonija, mitropolita Sankt-Petěrburgskago i Ladožskago, ot 21 ijulja 1903 goda. Cerkovnyja vedomosti, č. 31 (2. 8. 1903), s. 305-310, o zázracích na s. 308-309. Zázračná uzdravení si zaznamenali do deníků také velkokníže Sergej Alexandrovič a velkokněžna Olga Alexandrovna. Viz Dnevniki Nikolaja II, vol. 1, s. 779-780. 
carskou rodinu byl stvrzen. ${ }^{35}$ Mikuláš II. si pověsil ikonu sv. Serafima v pracovně.

Lidové slavnosti s účastí cara v sobě nepochybně nesly určité riziko. Podle vzpomínek Mosolova, při pěší procházce od sarovského „zázračného potoka“ zpět ke klášteru došlo k oddělení cara od svity, pouze Mosolov a gubernátor Launitz dokázali s Mikulášem držet krok, a cara brzy obklopil početný dav rolníků, kteří se tlačili, máchali rukama a hlasitě pokřikovali, přičemž div že cara nepovalili na zem. Mikuláš v bezpečí svižným krokem došel do kláštera, kdežto baron Vladimir Frederiks, ministr carského dvora podobné štěstí neměl, upadl, poranil se v obličeji a musel být ošetřen lékařem. S odstupem času se však právě podobné situace stávaly „důkazem“ sounáležitosti cara a lidu. Mosolov si uvědomoval nebezpečí „opakovaní Chodynky“, nicméně car si přál vyjádřit lidu svou „fyzickou lásku“, nebot’ při pobytu v Sarově vycítil přirozenou náklonnost, kterou k němu prostí lidé chovali. ${ }^{36}$

Prakticky všechny osoby, které se angažovaly při organizování sarovských slavností, byly dříve či později carem odměněny. Archimandrita Serafim byl v únoru 1904 jmenován představeným Voskresenského Novo-Jeruzalémského kláštera a 28. dubna 1905 povýšen na biskupa suchumského. Gubernátor Launitz obdržel hned v červenci 1903 titul řádného tajného rady, v prosinci 1903 byl jmenován nejvyšším štolbou carského dvora a car si na něho opět vzpomněl během kulminující revoluce v prosinci 1905. Svěřil mu významný post petrohradského gradonačalnika. ${ }^{37} \mathrm{Na}$ nedostatek carské přízně si nemohl stěžovat ani kníže Širinskij-Šichmatov. V prosinci 1903 jej car jmenoval tverským gubernátorem, v dubnu 1905 náměstkem vrchního prokurátora Nejsvětějšího synodu a nakonec v dubnu 1906 stanul v čele Synodu. Hned v červnu 1906 však úřad složil, nebot'nechtěl zasedat ve vládě řízené Petrem N. Stolypinem. Car jej bezprostředně jmenoval členem Státní rady a v té Širinskij-Šichmatov nepřetržitě zasedal až do revoluce v únoru 1917.

Mimořádná obliba nového světce u carevny i cara se nesetkávala s absolutním souhlasem, a to ani uvnitř širší romanovské rodiny. Negativní hodnocení masového využívání kultu sv. Serafima nalezneme například v pamětech velkoknížete Alexandra Michajloviče. Během rusko-japonské války bylo jednotkám odcházejícím na dálně-východní frontu žehnáno ikonou sv. Serafima, což na vojáky (údajně) mělo „nesmírně skličující dopad“, nebot’jeho tvář jim byla veskrze neznámá. Podle velkoknížete, když už bylo nezbytné „zaplést Boha a svaté do zločinů na Dálné východě, měli car a biskupové zůstat u starého, spolehlivého svatého Mikuláše ${ }^{38}$ který vedl řiši do bojů tři století. Na konci války to došlo tak daleko, že jsem nenáviděl byt' jen jméno sv. Serafima. Možná vedl nanejuýš zbožný život, ale jako patron bojových jednotek se ukázal naprosto nezpůsobilým. “39

35 Kromě carevny se v potoku vykoupala také velkokněžna Jelizaveta Fjodorovna (carevnina starší sestra) a švagrová, velkokněžna Olga Alexandrovna (sestra Mikuláše II.). V jejich případě se žádný zázrak nekonal, Jelizaveta zůstala bezdětná a Olze se první potomek narodil až roku 1917.

36 Mosolov, A. A.: Pri dvore imperatora, s. 104-105.

37 Gradonačalnik (doslova „městský velitel“), státní úředník s pravomocemi gubernátora, spravující gradonačalstvo, územně-správní jednotku vyčleněnou z gubernie. Většinou se jednala o významná města, například Petrohrad. Srov. Enciklopedičeskij slovar, vol. IXa, Petrohrad 1893, s. 492. 
Máme-li zhodnotit roli, jakou sehrálo svatořečení Serafima Sarovského v posilování státní ideologie a vylepšování obrazu cara, nelze než konstatovat, že výsledky dllouhodobě nebyly nikterak přesvědčivé. Mikuláš II. nepochybně dal lidu najevo svou zbožnost a oddanost pravoslaví, v dlouhodobé časové perspektivě však oslavy nic zásadního nezměnily. Prostí lidé si snad vážili cara, ale jakmile odjel, jejich život se vrátil do zaběhnutých kolejí. K státu chovali i nadále silně rezervovaný postoj, a jakmile se naskytla př́ležitost, zaútočili na jeden z jeho základů - soukromé vlastnictví. Právě tambovská gubernie, kde se sarovský klášter nacházel, byla během revoluce roku 1905 jedním z míst nejsilnějších rolnických bouří. Do konce roku 1905 zde rolníci vypálili na sto třicet šlechtických usedlostí a gubernátor von-der-Launitz o situaci v kraji v listopadu 1905 hlásil: „Rolnické hnutí prěkotně roste, mnoho statků bylo zničeno, statkári utíkaji, vojáki̊ je málo. Přsvědčováni nemá na lid žádný vliv. Je nezbytné povolat do gubernie armádu a zavést výjimečný stav. "

Rok 1905 byl nepochybně zlomovým momentem vlády Mikuláše II. Slovy historika Theodora Shanina, revoluce se stala okamžikem pravdy. ${ }^{41}$ Nebyla to pravda nikterá příjemná, protože odhalila křehkost piliŕrou uvarovské triády. Ř́jnovým manifestem (17. 10. 1905) se Mikuláš II. fakticky vzdal samoděržaví, nebot' na jaře 1906 byla zvolena Státní duma a země se stala konstituční monarchií. Základní zákony z roku 1906 byly fakticky ústavou (i když toto slovo se nikde oficiálně neužívalo), čímž v dějinách země nastal „epochálni moment", jak se později v emigraci vyjádřil liberál Vasilij Maklakov. ${ }^{42}$ Dle historika Borise Mironova ruský politický systém nyní odpovídal modelu „dualistické práuní monarchie“, přechodnému stavu před prosazením parlamentní monarchie nebo republiky. ${ }^{43}$ Problémem bylo, že car nový systém za svůj nikdy nepřijal. Pro Mikuláše II. nebyla východiskem z krize redefinice státní ideologie, ale opětovné zdůraznění jejích prvků, zejména pravoslaví a národa. Slovo samoděržaví z ruského politického slovníku sice nezmizelo, ale již nebylo používáno tak často jako před rokem 1905. Mikuláš II. se vnitřně nikdy nevyrovnal se vznikem Státní dumy a zůstal vězněm své archaické politické vize „duchovního spojení s lidem“, podle níž k vládě žádné „zprostředkovatelské instituce“ jako parlament nepotřeboval.

Léta 1907-1914 byla v Rusku obdobím konstantního hospodářského růstu a relativní politické stability. Relativní proto, že poměry se sice ve srovnání s roky 1905-1906 viditelně uklidnily, existovalo však permanentní pnutí mezi carem, vládou a Státní dumou, a to i navzdory konzervativní většině v Dumě. K napjaté atmosfére, diskreditaci režimu a posilování opozice vydatně přispívaly různé politické aféry. V letech 1911-1913 to byla Bejlisova aféra, postavená na vykonstruovaném antisemitském obvinění z rituální vraždy a v roce 1912 došlo k tzv. lenskému masakru, od něhož se odvíjel strmý nárůst dělnických stávek v roce $1913 .{ }^{44}$

40 Ascher, Abraham The Revolution of 1905. Russia in Disarray. Stanford 1988, s. 267-268.

41 Shanin, Theodor: Russia 1905-07: Revolution as a Moment of Truth. New Haven - London 1986. K první ruské revoluci dále srov. Pervaja revoljucija v Rossii. Vzgljad čerez stoletije. Moskva 2005.

42 Maklakov, Vasilij A.: Vlast’ i obščestvennost. Pariž 1936, s. 599-600.

43 Mironov, Boris N. Socialnaja istorija Rossijskoj imperii. vol. 2, s. 156-157.

44 Srov. Vydra, Zbyněk: Bejlisova aféra. Antisemitismus a ruský politický život v letech 1911-1913, Theatrum his- 
Souběžně s tím zasáhla Rusko ,jubilejní horečka“.45 Vzhledem k porážkám a otřesům, které země na počátku 20. století utrpěla, se nezdálo, že by existovalo mnoho důvodů k oslavám. Opak byl pravdou. Monarchie potřebovala upevnit svoji pozici a ukázat velikost ruské ŕíše. Největší oslavy po roce 1906 tudíž připomínaly momenty z dějin budování impéria a hrdinské chvíle ruského národa: v roce 1909 dvousetleté výročí bitvy u Poltavy, v roce 1912 stoleté výročí připojení Besarábie a především výročí bitvy u Borodina. ${ }^{46}$ Vrcholem těchto oslav se mělo stát jubileum romanovské dynastie v roce 1913.

Oslavy třísetleté vlády Romanovců mohly více než cokoli jiného vyjádřit životaschopnost monarchie a potvrdit, že nedávná politická krize byla překonána. Nástup Romanovců na carský trůn v roce 1613 ukončil období tzv. smuty (smutnoje vremja), vleklé politické krize ruského státu na přelomu 16.-17. století. ${ }^{47}$ Paralela nedávných událostí se smutou byla zjevná, podobně jako počátku 17. století se ruská monarchie ocitla na pokraji zhroucení. A při výkladu událostí nacházeli monarchisté, stejně jako v případě Smuty, především vnější příčiny. Tehdy to byla polsko-litevská intervence, nyní rozkladné působení ideologií importovaných z Evropy (liberalismus, socialismus) a rozvratná činnost neruských národů, zejména Židů. Navíc se daly postavy hrdinů z časů smuty využít pro posílení carské ideologie. Kupec Kuzma Minin a kníže Dmitrij Michajlovič Požarskij postavivší se do čela odboje proti Polákům, či rolník Susanin, podle legendy zachránce cara Michajla Romanova, byli ideálními vzory. Reprezentovali různé stavy a společně bojovali za cara, Rusko a pravoslavnou víru. ${ }^{48}$

Jubilejní oslavy měly definitivně odvát přízrak revoluce a překlenout též aktuální problémy. Mikuláš II. od oslav očekával, že budou demonstrovat jednotu ruského národa a věrnost lidu romanovské dynastie. Stále byl pevně přesvědčen, že mezi carem a lidem existuje neviditelné pouto, a on jako panovník $z$ Boži milosti dokáže vycítit potřeby svých

toriae 1, 2006, s. 203-231; Melancon, Michael: The Lena Goldfields Massacre and the Crisis of the Late Tsarist State.College Station, Texas 2006.

45 Tsimbaev, Konstantin: Die Orthodoxe Kirche im Einsatz für das Imperium. Kirche, Staat und Volk in den Jubiläumsfeiern des ausgehenden Zarenreichs. Jahrbücher für Geschichte Osteuropas 52 (2004), č. 3, s. 355-369, zde s. 355.

46 Naproti tomu 50. výročí zrušení nevolnictví v roce 1911 proběhlo relativně skromně, bez většího zajmu cara a vládních úřadů. Wortman, R: Scenarios, s. 377-382. Schneider, Kurt: 100 Jahre nach Napoleon. Russlands gefeierte Kriegserfahrung, Jahrbücher für Geschichte Osteuropas, 49 (2001), č. 1, s. 45-66.

47 Literatura ke smutě je velice rozsáhlá, z nejvýznamnějších prací srov. Platonov, Sergej F.: Očerki po istorii smuty v Moskevskom gosudarstve XVI-XVII vv. Moskva 19955; Skrynnikov, Ruslan G.: Rossija v načale XVII. v. „Smuta“. Moskva 1988; Perrie, Maureen: Pretenders and Popular Monarchism in Early Modern Russia. The False Tsars of the Time of Troubles. Cambridge 1995; Dunning, Chester S. L.: Russia's First Civil War. The Time of Troubles and the Founding of the Romanov Dynasty. University Park 2001. Pro základní přehled srov. Perrie, Maureen: The Time of Troubles (1603-1613). In: The Cambridge History of Russia. Vol. 1. From Early Rus' to 1689, Ed. M. Perrie. Cambridge 2006, s. 409-431.

48 Zejména postava Ivana Susanina se stala v průběhu 19. století nedílnou součástí ruské národní tradice. Zasloužila se o to především opera Michaila Ivanoviče Glinky Život za cara (Žižn za carja, premiéra v Petrohradě v roce 1836), obecně uznávaná jako prototyp ruské národní opery. Srov. Wortman, Richard: Scenarios, s. 160-161; podrobněji Maes, Francis: A History of Russian Music. From Kamarinskya to Babi Yar. Trans. by A. J. Pomerans - E. Pomerans. Berkeley - Los Angeles - London 2006, s. 17-24. 
poddaných. Předsedovi vlády Petru A. Stolypinovi v tomto duchu napsal: „Lid musí vědět, že jeho starosti a radosti leži carovi na srdci “.49

Jubileum bylo velkým tématem pro ruský tisk, od konce ledna se pravidelně objevovaly články o historii romanovské dynastie, okolnostech nástupu Michaila Romanova na carský trůn, doprovázené desítkami fotografií a kreseb. Vlastní průběh oslav byl zachycen sériemi podrobných reportáží. ${ }^{50}$

Oslavy byly rozděleny na tři části. 21. až 24. února se konaly ceremonie v Petrohradě, tehdy bylo připomínáno zvolení Michaila Romanova carem. V druhé polovině května Mikuláš II. podnikl cestu Horním Povolžím a pout’ zakončil v Moskvě 24. až 27. května. Účast pravoslavné církve na oslavách byla samožrejmostí. ${ }^{51}$ Oficiální církevní tisk ukazoval věrnost ruského obyvatelstva carovi ${ }^{52}$; Cerkovnyja vedomosti otiskly desítky telegramů, které 21.-22. února dorazily do Nejsvětějšího synodu, byly adresovány carovi a prokurátor Synodu Vladimir K. Sabler je slavnostně předal Mikuláši II. Všechny vyjadřovaly lásku a věrnost carovi, pravoslavné víře a Rusku. ${ }^{53}$ Romanovské jubileum doprovodila (10.-12. května) kanonizace patriarchy Jermogena, který zemřel v polském zajetí v Moskvě roku 1612. Oslavy připomínající Jermogenovu mučednickou smrt zůstaly především církevní záležitostí, účastnila se jich nejvyšší hierarchie pravoslavné církve a přijel antiošský patriarcha Grigorij IV. ${ }^{54}$

Pro cara měla zvláštní význam především cesta Povolžím a návštěva Moskvy. Trasa Povolžím byla v mnoha ohledech symbolická, nebot' do značné míry kopírovala cestu, po níž směřovali v roce 1612 Kuzma Minin a kníže Dmitrij Požarskij na pomoc Moskvě. Navíc procházela městy, jež hrála významnou roli v ruských dějinách, byla spojena s mnohými panovníky středověké Rusi a rodovou historií Romanovců. Pro carevnu Alexandru se jednalo o vůbec první setkání se starými ruskými městy a zjevně se na cestu těšila. Nejvíce ji zajímaly kláštery. Těch nakonec carská rodina během deseti dnů navštívila

49 Perepiska N. A. Romanova i P. A. Stolypina, Krasnyj archiv 5 (1924), s. 122.

50 Srov. např. časopis Ogoňok. Ježenědělnyj chudožestvenno-literaturnyj žurnal, č. 3 (20. 1. 1913), č. 4. (27. 1. 1913), zde byly fotografie z Kostromského muzea Romanovců; dále obrazová reportáž o natáčení scén zpodobňujících události roku 1913. V historických lokalitách Moskvy, Kostromy a Jaroslavli, v dobových kostýmech a kulisách, byly zinscenovány scény setkání bojarské delegace s Michailem Romanovem, jeho slavnostní uvítání v Jaroslavli a Moskvě a další); č. 22 (2. 6. 1913), série fotografií z carské cesty Povolžím, zejména z pobytu v Nižním Novgorodě a Kostromi; č. 23 (9. 6. 1913), série fotografí́ z carského pobytu v Jaroslavli, Rostově Velikém a červnové náv̌stěvy Moskvy.

51 Učastije Cerkvi i duchovenstva v velikijich sobytijach trista let nazad. In: Pribavlenija k cerkovnym vedomostjam, č. 7-8 (21. 2. 1913), s. 329-332. Text připomínající významnou roli církve ve volbě Michaila Romanova carem (srov. např. větu „Volba Romanovců je přímo a výlučně dílo církve.“) napsal protojerej Ioann Vostorgov, jeden z nejaktivnějších vůdců ultrapravice v Moskvě. K osobě Vostorgova srov. Vydra, Zbyněk: Život za cara? Krajní pravice v předrevolučním Rusku. Červený Kostelec 2010, s. 278-281 ad.

52 Toržestvennoje prazdnovanije v S.-Petěrburge 300-letija Doma Romanovych. In: Pribavlenija k cerkovnym vedomostjam, č. 9 (2. 3. 1913), s. 386-397; Prazdnovanije trechsotletija Doma Romanovych v Moskve, Tamtéž, s. 397-400; Jubilejnoje toržestvo 21 fevralja v g. Kostrome, Tamtéž, s. 400-401; Jubilejnyja toržestva. Putešestvije Ich Imperatorskich Veličestv, Tamtéž, č. 22 (1.6. 1913), s. 1007-1053.

53 Vsepoddanejšija telegramy, Cerkovnyja vedomosti, č. 9 (2. 3. 1913), s. 73-87; č. 10, s. 98-113.

54 Ogoňok, č. 20 (19. 5. 1913). Srov. Narodnaja vera v svjatost patriarcha Jermogena ot jego vremeni $i$ do našich dnej. In: Pribavlenija k cerkovnym vedomostjam, č. 21 (25. 5. 1903), s. 931-936; Dni svetlogo toržestva v Moskve, Tamtéž, s. 961-974; Tamtéž, č. 22 (1. 6. 1913), s. 1055-1057. Srov. Tsimbaev, K.: Die Orthodoxe Kirche, s. 357. 
čtyřiačtyřicet (!), takže pro mnohé pozorovatele se jednalo spíše o „náboženskou pout a „soukromou rodinnou oslavu“, než státní a národní svátek. ${ }^{55}$

Oslavy romanovského výročí ovšem jednoznačně vycházely z podstaty carské státní ideologie. Návštěva klášterů mezi Vladimirem a Moskvou nebyla (pouze) projevem osobního náboženského zaujetí, ale zdůrazněním významu pravoslaví jako jednoho z úhelných kamenů ruské státní a národní identity. Samoděržaví bylo zosobněno v carovi samém a jeho vystupování na veřejnosti. A cesta etnicky ruskými kraji, zakončená v Moskvě, podtrhla národní (lidový) ráz oslav.

Romanovské jubileum se odehrávalo v jiném politickém kontextu než slavnosti v Sarově roku 1903. Především zde byla Státní duma a různé politické strany. Oficiálně měly být oslavy jubilea nadstranické, car kladl důraz na přímý kontakt s lidem (zejména rolníky) a k tomu nepotřeboval žádné prostředníky. Většina politických stran se také v oslavách nehodlala angažovat. Výjimkou byl tábor ultrapravice, který viděl příležitost vyjádřit veřejně podporu carovi a zviditelnit se u dvora i v celostátním měřítku. Paralelně k státem připravovaným oslavám tedy vznikl výbor monarchistických organizací a do Petrohradu byl záměrně na únorové dny jubilea svolán VI. Všeruský sjezd ruských lidí. ${ }^{56}$ Představitelé ultrapravých stran se na sjezdu překonávali v patriotismu, projevech oddanosti carovi a vyzdvihování státní ideologie, včetně samoděržaví. ${ }^{57}$

Ultrapravice výrazně participovala na oslavách romanovského jubilea. Delegace Svazu ruského lidu z Počajevského kláštera přivezla do Petrohradu ikonu Panny Marie Počajevské. ${ }^{58}$ Nejprve ji vystavila v Jekatěrinském chrámu v Carském Selu, druhý den (18. února) ji převezla do hlavního města, kde se jí na carskoselském nádraží poklonil metropolita Vladimir a další významní duchovní (např. volyňský arcibiskup Antonij, velký podporovatel Svazu ruského lidu). Zástupci ultrapravice byli př́ítomni na hromadné audienci u cara v Zimním paláci. Mikuláš II. s největší pravděpodobností nerozlišoval, kdo mu provolává slávu, pro liberálně orientovanou veřejnost však přítomnost ultrapravice v Zimním paláci a celkově její aktivní vystupování během oslav znamenalo diskreditaci jubilea a pouze další potvrzení toho, že romanovská monarchie je jen obtížně reformovatelná. ${ }^{59}$

V této souvislosti nelze pominout otázku, do jaké míry byla na ultrapravé skupiny napojena pravoslavná církev. Jedná se o problém opravdu složitý. Ultrapravice se hlásila k oficiální státní ideologii; symboly jí užívané se vztahovaly k ruské historii a pravoslaví, vyjadřovaly sílu, vítězství nad nepřáteli Ruska a křestanské víry. Hlavní ultrapravicová

55 Bogdanovič, Jevgenij J.: Istoričeskoje palomničestvo našego carja v 1913 godu. St. Petersburg 1914; Kokovcov, Vladimir N.: Iz mojego prošlogo, vol. 2, Paris 1933, s. 155-156.

56 Všeruské sjezdy byly hlavním místem veřejné prezentace ultrapravicové politiky a ideologie a jejich tradice sahala do roku 1906. Srov. Vydra, Z.: Život za cara?, s. 192-201.

57 Pravyje partii. Dokumenty i materialy. Vol. 2. 1910-1917gg. Moskva 2001, s. 316-317.

58 Prybytije v Peterburg čudotvornoj ikony Počajevskoj Božiej Materi, in: Pribavlenija k cerkovnym vedomostjam, č. 7-8 (21. 2. 1913), s. 356-357.

59 S přítomností ultrapravice na oslavách, zejména na slavnostní audienci v Zimním paláci, nesouhlasili ani lidé plně loajální k monarchii, např́íklad náměstek ministra vnitra generál Džunkovskij, zodpovědný za bezpečnost během jubilea. Džunkovskij, Vladimir F.: Vospominanija. Vol. 2. Moskva 1997, s. 155-156. 
strana Svaz ruského lidu měla ve znaku Sv. Jiřího Vítězného (Georgije Pobědonosce), který zabil draka tradičně symbolizujícího nepřítele pravé církve. Kult sv. Jiří byl spojen s církevní tradicí staré Rusi od samého počátku (mince a pečeti Kyjevské Rusi; klášter Sv. Jiří v Kyjevě založený Jaroslavem Moudrým); sv. Jiřri byl hlavním světcem pomáhajícím v boji proti nepřátelům země a od časů Dmitrije Donského též patronem Moskvy. K Sv. Jiří se obracela také hymna Svazu ruského lidu. Dalším příkladem použití náboženské symboliky byl název politické strany založené Vladimirem Puriškevičem - Ruský lidový svaz archanděla Michaela. Podle tradice vedl archanděl Michael anděly v boji proti Satanovi a jeho stoupencům. Boj a válka byly pro ultrapravici jedním z centrálních témat: téměř všechny ikony oblíbené a použivané ultrapravicí byly spojeny s důležitými vítězstvími ruských dějin: ikona Panny Marie Kazaňské (zachránila Moskvu před Poláky během smuty - přivezl ji z Kazaně oddíl knížete Dmitrije Požarského); ikona Panny Marie Vladimirské (měla ovlivnit tažení Andreje Bogoljubského proti povolžským Bulharům a sehrála roli v bitvě u Borodina); ikona Panny Marie Smolenské (vítězství nad Napoleonem). Ikona Panny Marie Gerbovecké sloužila jako patronka (ruské) Besarábie a byla užívána v souvislosti s jejím „osvobozením“ ruskými vojsky v roce 1812.

Všeruské sjezdy ultrapravicových stran byly naplněné pravoslavnou symbolikou a církevními rituály a obřady: sborové scény z oper (Život za cara; Kniže Igor) byly stř́íány s náboženskými zpěvy (Christos voskres). Téma Kristova vzkříšení se všude objevovalo jako symbol vítězícího křestanství a vzkříšení Ruska. Při všech veřejných vystoupeních krajní pravice se konala církevní procesí, z nichž se takto stávala specifická forma politické demonstrace. Lídři ultrapravice se „schovávali“ za ikony Panny Marie, Krista či různých světců a tím přestávali být „obyčejnými politiky“. Stávali se „chráněnci“ sv. Vladimíra, sv. Jiří ad., čímž jejich legitimita byla posilována. Slovy historika Heinze-Dietricha Löweho: „Političtí vưdci potřebovali něco více než jen legitimitu volebni urny. “60

Pravoslavná církev se od politiky obvykle distancovala, a to včetně ultrapravicové. Však také oficiální církevní tiskoviny vydávané Synodem ve zprávách o průběhu romanovského jubilea nikterak nereferovaly o Všeruském sjezdu ruského lidu a též reportáž o ikoně Panny Marie Počajevské vůbec nezmiňovala, že ji do hlavního města přivezla pobočka Svazu ruského lidu ${ }^{61}$ Odstup od politiky ovšem v praxi nebyl vůbec důsledný. Kněží mohli být voleni, a také byli, do Státní dumy, a rovněž zasedali ve Státní radě. Nejenže na všech sjezdech ultrapravých stran byli mezi čestnými hosty významní hodnostáríi pravoslavné církve, ale duchovní se prrímo angažovali v politických stranách. Protojerej Ioann I. Vostorgov stál v čele moskevské Ruské monarchistické strany v letech 1907-1913. V Caricynu byl velkým patronem ultrapravice biskup Jermogen ${ }^{62}$, několik duchovních bylo zvoleno za ultrapravici do Státní dumy, například Mitrofan, biskup

60 Löwe, Heinz-Dietrich: Political Symbols and Rituals of the Russian Radical Right, 1900-1914. Slavonic and East European Review, č. 3 (1998), s. 450.

61 Prybytije v Peterburg čudotvornoj ikony Počajevskoj Božiej Materi. In: Pribavlenija k cerkovnym vedomostjam, č. 7-8 (21. 2. 1913), s. 356-357.

62 Jermogen (Georgij Je. Dolganov, 1858-1918), saratovský a caricynský biskup v letech 1903-1912, patřil k nejkonzervativnějším představitelům pravoslavného episkopátu v Rusku. Srov. Černaja sotnja. Istoričeskaja enciklopedija, s. 139-142. 
gomelský (1907-1912) byl poslancem III. Státní dumy za Svaz ruského lidu (zvolen v minské gubernii). Archimandrita Serafim (Čičagov), významný svým podílem na kanonizaci Serafima Sarovského, byl rovněž aktivní v ultrapravicovém hnutí, účastnil se Sjezdů ruských lidí a byl čestným členem Svazu ruského lidu. Zvláštní místo ve struktuře ultrapravicových stran měl již zmíněný Počajevský oddíl Svazu ruského lidu. Fungoval na bázi Počajevského kláštera, jeho předsedou byl archimandrita Vitalij a patronem volyňský biskup Antonij. ${ }^{63}$ Počajevský klášter byl od roku 1906 až do první světové války centrem ultrapravice ve volyňské gubernii, vycházely zde noviny Počajevskij listok proslulé antisemitskou propagandou i sociálním radikalismem.

Nelze ovšem tvrdit, že pravoslavná církev byla „reakční silou“; poměry uvnitř ní byly velice složité. Vyšší klérus se orientoval výrazně konzervativně a pravicově a byl úzce spojen s carským režimem. Řada níže postavených kněží smýšlela rovněž nacionalisticky a inklinovala k ultrapravici. Na druhou stranu mnoho kněží na úrovni farností tíhlo k revolučnímu radikalismu, dovolávalo se reformy církve i reforem politických a sociálních, včetně pozemkové reformy aj. ${ }^{64}$

U romanovského jubilea, podobně jako u svatořečení Serafima Sarovského je nutné si položit otázku, jak byly oslavy přijímány veřejností a do jaké míry fungovala propagace státní ideologie. Hodnocení př́ímých aktérů oslav byla rozporuplná. Mikuláš II. byl navýsost spokojen. Z jeho pohledu zejména cesta Povolžím ukázala, „že pouto mez carem a lidem, kterým se vyznačovala Matička Rus za starých časů, existuje nezničitelně právě tak $i$ dnes. "65 Generál Džunkovskij vzpomínal na oslavy především s úlevou, že se obešly bez konfliktů. Bylo to ovšem za cenu velmi přísných bezpečnostních opatření, takže se dalo i vážně pochybovat o spontaneitě nadšení, jestliže se davy vítající cara skládaly $\mathrm{z}$ valné části z prověřených osob či přímo agentů tajné policie, jak tomu bylo především ve velkých městech. ${ }^{66} \mathrm{~V}$ převážně rolnických a Rusy obydlených guberniích Horního Povolží mohly být projevy úcty k carovi autentičtější než v Petrohradě či Moskvě. Však také Mikuláš II. byl nadšený a odnesl si z cesty závěr, že země je vůči němu loajální a přízrak revoluce definitivně zmizel. Od toho se měla odvíjet i pevnější politika vlády a neustupování opozici ve Státní dumě. Bylo však lehkomyslné činit závěry z momentálního nadšení a výkřiků davu. Titíž rolníci, kteří před carem padali v slzách na kolena a provolávali mu slávu, se nijak podstatně nelišili od rolníků, kteří se před deseti lety klaněli ostatkům Serafima Sarovského a krátce nato rabovali šlechtické statky. Což se mělo opakovat čtyři roky po romanovském jubileu.

Mikuláš II. věřil v duchovní spojení mezi sebou jako carem a ruským lidem. Rusko v roce 1913 však zdaleka nebyli pouze ruští rolníci, přičemž i jejich oddanost vưči státu byla křehká. Společnost byla velmi různorodá z hlediska sociálního a etnického slože-

63 Antonij (Alexej P. Chrapovickij, 1863-1936), volyňský a žitomirský biskup (od 1906 arcibiskup) v letech 1902-1914. V roce 1920 emigroval, v letech 1921-1936 řídil Ruskou pravoslavnou církev v zahraničí. K Počajevskému oddílu Svazu ruského lidu viz Vydra, Z.: Život za cara?, s. 170-173.

64 Freeze, Gregory L.: Orthodox Church, s. 302-303.

65 Cit. Podle Wortman, R.: Scenarios, s. 395.

66 Srov. Vydra, Zbyněk „Není Rusko bez cara“. Romanovské jubileum v roce 1913. Theatrum historiae 2 (2007), s. 332-333. 
ní i politických názorů. Státní ideologie zdaleka nekonvenovala všem Rusům, o jiných etnikách nemluvě. Koncepce lidového monarchismu nebyla ze strany carského dvora a vlády prosazována málo, ale míjela se s vizemi a přáními podstatné části obyvatelstva. Většině rolníků šlo především o rozdělení půdy a bylo v jim zásadě jedno, od jakého režimu ji dostanou. Radikální socialisté odmítali monarchii jako takovou a liberálové si nejvíce přáli „buržoazní monarchii“. Jenže Mikuláš II. i po roce 1906 odmítal „vyklidit pole“ a stát se pouhým symbolem jakým byli např́íklad britští panovníci. ${ }^{67}$ Pravoslaví sice tvořilo první článek státní ideologie, nebylo ovšem oním pomyslným tmelem držícím společnost a stát pohromadě. Pominout nelze skutečnost, že miliony ruských pravoslavných věřících chovali více než vlažný vztah k instituci pravoslavné církve. Podle všeruského sčítání lidu z roku 1897 žilo v zemi 2,2 milionu staroobřadníků a členů různých sekt. Ve skutečnosti jich nepochybně bylo mnohem více, protože lidé z obavy před úřední šikanou a pronásledováním ze strany policie skutečné přesvědčení tajili. Odborníci odhadují, že k staroobřadnictví se hlásilo až 20 milionů pravoslavných věřících. ${ }^{68}$ Ruská společnost zůstávala silně zbožná ${ }^{69}$, to však neznamenalo loajalitu k státu a režimu. Ưředně prosazované pravoslaví trpělo provázáním s dalšími prvky triády a také tím, že pravoslavná církev byla př́liš dlouho v područí státu/samoděržaví a neměla ve společnosti patřičnou autoritu.

67 Historička Eva Giloi upozorňuje na obdobný problém v případě císařského Německa, v kterém byla koncepce buržoazní monarchie a občanská společnost podstatně rozvinutější než v Rusku. Popularita Viléma II. klesala souměrně s tím, jak se snažil prosadit svůj „osobní režim“. Chtěl mít více politického vlivu, nehodlal ustupovat do pozadí a tak se střetával s hodnotami buržoazního světa. Eva Giloi, Monarchy, Myth, and Material Culture, s. 330.

68 Pervaja russkaja revoljucija, s. 55.

69 Na rozdíl od západní Evropy nedocházelo v Rusku na přelomu 19. a 20. století k oslabení religiozity. Srov. Freeze, G. L.: Orthodox Church, s. 298-299. 


\section{The Orthodoxy as a Part of the Public Presentation of the Romanov Monarchy under Nicholas II}

Since 1830's, Russian monarchy had the official state ideology, called „official nationality“, composed from three elements: „Orthodoxy, Autocracy, Nationality“. The continuity of the ideology was one of the striking features of the tsarist regime until its fall in February 1917. The article is focused on the role of Orthodoxy in the creating of public image of monarchy, especially under the last Emperor Nicholas II. Author analyzes two public events connected closely with the Orthodoxy, in which Nicholas II played a key role. The canonization of Serafim of Sarov in 1903 and the celebration of the Romanov Tercentenary in 1913 were conceived as a great public festivities which had to bring the emperor and the people together. Both events presented the tsar as very pious man who cared deeply for the people. However, the long-term effect of such presentation was dubious, because the folk, mostly peasants, remained rather indifferent to the state ideology "orthodoxy, autocracy, nationality". Although the peasants were largely devout, they became more and more anxious about the Orthodox Church which suffered from its long subordination to the autocratic state. 